\title{
Disability as a 'New' Global Social Theme: The Role of International Organizations in an Expanding Global Policy Field
}

\author{
Johannes Schuster and Nina Kolleck
}

\section{INTRODUCTION}

Disability as a global social policy issue has gained increasing importance during recent decades. Largely responsible for this development has been a shift in the general conceptualization of disability - from a medical perspective that views disability as a person's limitations to the perception of disability as limitations imposed by society. After many years of struggle for recognition, the adoption in 2006 of the Convention on the Rights of Persons with Disabilities (CRPD) by the United Nations (UN) represented a seminal step in establishing disability as a human rights issue. Due to this new acknowledgment of disability as a global social policy issue, a

\footnotetext{
J. Schuster $(\bowtie) \bullet$ N. Kolleck

Institute of Political Science, Leipzig University, Leipzig, Germany

e-mail: johannes.schuster@uni-leipzig.de; nina.kolleck@uni-leipzig.de

(C) The Author(s) 2021

K. Martens et al. (eds.), International Organizations in Global

Social Governance, Global Dynamics of Social Policy, https://doi.org/10.1007/978-3-030-65439-9_9
} 
global organizational field ${ }^{1}$ with a variety of different international actors has emerged around the topic, with strong involvement by International Organizations (IOs).

Today, global policy is no longer made by nation states alone but includes a heterogeneous set of different public and private stakeholders, such as IOs and non-governmental organizations (NGOs) (Jakobi 2009). The concept of global governance underlines the influence of non-state actors in the interplay with state actors in relation to a specific policy (Rosenau 1995; Zürn 2018). Moreover, the diverse actors of an organizational field are interdependent, which means that they build networks to form alliances and disseminate information in order to strengthen their positions (Adam and Kriesi 2007). IOs often have a particular mandate that allows them to act in a frame predefined by their member states. However, public administration scholars have agreed that IOs and their administrations exert additional political influence by shaping discourses and setting agendas for specific topics (Barnett and Finnemore 1999; Bauer et al. 2017). This means that the traditional principal-agent modelwith leading nation states as principals creating international regimes as their agents that work on predefined problems - is outdated in some fields of social policy, making it particularly interesting to investigate the role of IOs.

An investigation of the population of IOs in a specific social policy field needs to consider two approaches: the organizational environment and the intrinsic features (Abbott et al. 2016). Whereas the organizational environment encompasses the general characteristics of a policy field (i.e., the beliefs and norms) as well as the involved actors and their relationships (i.e., the social networks), the intrinsic features relate to the inherent characteristics of organizations (such as membership rules and thematic orientation) and the way these define an organization's scope of action (Niemann et al. in this volume). As there is still only limited knowledge about the population of IOs in disability policy, the aim of this chapter is to introduce disability as a global social policy theme and to identify important actors, with a particular focus on IOs. ${ }^{2}$ First, we give an overview

\footnotetext{
${ }^{1}$ We refer to the concept of organizational field as 'the aggregate of actors' of a policy field, which further includes the rules and belief systems, as well as the relational networks that arise in the broader societal context (see Niemann et al. in this volume).

${ }^{2}$ Most studies on the topic of global disability policy and the CRPD, which will also be discussed in this chapter, either focus on the historical development or describe the content and status quo of the CRPD (e.g., Della Fina et al. 2017; Arnardóttir and Quinn 2009;
} 
of the policy field and its development from a global perspective and present the main IOs in terms of their involvement in disability policy. In order to approach a mapping of the organizational field of global disability policy, we identify the most central actors and their connections based on Twitter data. We then present the main topics discussed in the field, followed by a short conclusion of the chapter.

\section{Background of (Global) Disability Policy Discourse AND INVOLVEMENT OF IOs}

In general, disability policy is a comparably novel topic of social policy. Before the twentieth century, persons with disabilities were mostly hidden from society, and it took governments until the end of the Second World War to explicitly address the needs and rights of disabled persons through policies. According to Drake (1999, 36-41), domestic disability policies can be evaluated along a spectrum from policymaking that denies disability rights, to an approach that seeks to identify individual disadvantages in order to provide necessary services for adjustment, to a social approach where disabled people are accorded the rights to participate in society as equal citizens. For a better understanding of disability in both national and global context, two main concepts can be distinguished: the medical model $^{3}$ and the social model of disability (Kayess and French 2008; Harpur 2012). In this section, the two models are explained and related to IOs, thereby partly describing the intrinsic features of these IOs. Subsequently, an additional model - the economic model—is presented and the role of regional organizations is briefly discussed.

\section{The Medical Model and WHO}

The medical model of disability conceives of disability as "a personal tragedy" and focuses on the "affliction caused by the particular condition or impairment and the provision of cure, treatment, care and protection to change the person so that they may be assimilated to the social norm" (Kayess and French 2008, 5). Thus, in this model the limitations are

Kayess and French 2008) and disability policy (e.g., Barnes and Mercer 2004; Oliver 1996), but lack more detailed information about actors and processes in global disability governance.

${ }^{3}$ Other scholars, such as Oliver (1996) or Priestley (1998), refer to the medical model as the "individual model", but describe the same concept. 
caused by the impairment itself, neglecting the role of the social environment and the barriers it builds. In social policymaking, this conception has led to disability policies that categorized persons with disabilities according to their disadvantages and that urged them to adjust according to their unique and individual needs, for example, the Chronically Sick and Disabled Person's Act (1970) and the Disability Discrimination Act (1995) in the UK (Priestley 2000) or the Rehabilitation Act (1973) in the USA (Barnes 2011). This model enhanced welfare policies to support the disabled individuals in their adjustment, such as accommodating them in separate houses or providing financial support and care (Priestley 2000). Inherent in such an approach is an increased expenditure on health care and research (Jeon and Haider-Markel 2001). These attempts created a whole new professional system of welfare that aimed to rehabilitate persons with disabilities. This, in turn, exempted persons with disabilities from (labor-related) duties and established and institutionalized a climate of societal segregation (Drake 1999).

The one IO that is closely intertwined with the medical model is the World Health Organization (WHO). In order to establish universal definitions for different forms of disability and impairment, WHO published the International Classification of Impairments, Disabilities, and Handicaps (ICIDH) in 1980. The document was divided into three categories, impairments, disabilities, and handicaps, with concise definitions for each (WHO 1980, 27-29). The classification system was used for the assignment and provision of services and benefits. This focus of WHO on the medical model lasted until the beginning of the twenty-first century. The organization then replaced the ICIDH with its International Classification of Functioning Disability and Health (ICF) and thereby adopted-at least to some extent- the social model (Barnes 2011). Other activities of WHO include the community-based rehabilitation guidelines-published in close cooperation with other inter-governmental and non-governmental actors (e.g., the International Labour Organization (ILO), UNESCO, or the International Disability and Development Consortium (IDDC)) which mainly cover the provision of medical support (Lang et al. 2011), or the World Report on Disability, published together with the World Bank, which provides a comprehensive outline of the status quo around persons with disabilities and provides suggestions for all sorts of different stakeholders (WHO 2011). 


\section{The Social Model and the UN}

In contrast to the individual model, the social model of disability states that "contingent social conditions rather than inherent biological limitations constrain individuals' abilities and create a disability category" (Stein 2007,85 ). This concept-which was promoted by a growing disability rights movement that started to emerge in the 1960s, particularly in the US and the UK-shifts the focus from the impairment itself to the society as the cause of barriers (Kayess and French 2008). The movement was substantially led by the British disability rights network known as the Union of Physically Impaired Against Segregation, which rejected more mainstream ideas in order to enforce the acknowledgment of the social model (Shakespeare 2010). This sociopolitical or rights-based approach to disability policymaking implied that the adjustment of the physical environments of disabled persons to their needs was what was necessary, rather than a "medical repair" of the concerned persons themselves (Jeon and Haider-Markel 2001, 216).

In tracing the development of the disability rights movement and thus the emergence and acceptance of the social model, we can see that they are closely interlinked with the UN (Degener and Begg 2017; Stein 2007). The first non-binding declarations, such as the Declaration on the Rights of Mentally Retarded Persons in 1971 and the Declaration on the Rights of Disabled Persons in 1975, still tended to emphasize individuals' medical needs. In contrast, by declaring the year 1981 the official International Year of Disabled Persons-which was succeeded by the International Decade of Disabled Persons (from 1983 to 1992) — the UN gave particular attention to the rights and interests of persons with disabilities (Stein 2007). A seminal step was then made with the adoption of the Standard Rules on the Equalization of Opportunities for Persons with Disabilities in 1993, which although only "soft law and legally unenforceable" (Stein 2007,89) nevertheless represented an initial UN instrument that exhorted member states "to ensure the equalization of opportunities for disabled persons" (Stein 2007, 89). Until today, the Standard Rules are conceived as a leading watershed in the development of global disability rights. Finally, at the beginning of the new millennium, disability rights successively became a human rights issue worthy of their own convention, having been promoted by individual states (such as Mexico and New Zealand) as well as scientific studies which looked at the neglect of disabled persons in the core human rights conventions beyond the medical perspective. 
The convention itself was discussed and drafted by an Ad Hoc Committee which was established in December 2001 and included significant involvement by civil society organizations. After a process of eight sessions, the final document was adopted in December 2006 and came into force in May 2007 (Degener and Begg 2017).

Today, the UN is the driving force in global disability policy. The implementation of the Convention is monitored by the Committee on the Rights of Persons with Disabilities, which is located at the Office of the High Commissioner for Human Rights in Geneva. Signatories are obliged to submit reports on the progress of the implementation of the CRPD every four years. The Committee then evaluates the reports and returns general observations, including recommendations for further implementation. Moreover, the main tasks of the Committee comprise the preparation of General Comments on specific issues of the Convention as well as the examination of individual complaints (Uerpmann-Wittzack 2018). It should be noted that as well as the Committee's other tasks, the development of the reports is exercised in close consultation with different nonstate actors, foremost disabled persons' organizations (DPOs).

Besides the Committee and its administration, the main focal point of the CRPD and disability rights at the UN is the CRPD secretariat, which is located at the UN headquarters in New York. The secretariat falls within the Division for Inclusive Social Development (DISD) of the UN Department of Economic and Social Affairs (UNDESA). The secretariat is established to promote the international normative framework on disability, to support other inter-governmental bodies concerning disability rights issues and to service the annual Conference of States Parties (COSP) (UN Enable 2020). The COSP represents-for human rights treaties in particular - an innovative mandate and provides a forum for constant exchange and discussion between member states, IOs, and civil society organizations (de Búrca et al. 2013).

However, the promotion of disability rights in the UN is not limited to the main bodies, but also brings together other UN divisions and specialized agencies, such as the UN Educational, Scientific and Cultural Organization (UNESCO), the UN Children's Fund (UNICEF), and the World Bank. UNESCO is an official supporter of the CRPD and has adopted an action plan including "research and evidence-based data collection, development of policies and strategies on inclusion of persons with disabilities, building an enabling environment and raising awareness, development of appropriate tools for instruction and capacity building" 
(UNESCO 2020). In doing so, UNESCO places a strong emphasis on the promotion of inclusive information and communication technologies (ICTs), as can be seen from the publication of model policies for inclusive ICTs to support UNESCO member states in the implementation of specific issues concerning disability policy (Watkins 2014). Whereas the focus of UNESCO is linked strongly to the CRPD, UNICEF's concern with disability rights has been an integral part of their work since the Convention on the Rights of the Child (CRC) (see also Holzscheiter in this volume). Predominantly focusing on the rights of children with disabilities as "one of the most marginalized and excluded groups in society" (UNICEF 2020), UNICEF follows three disability goals. First, it commits itself to being "an inclusive organization for all" (UNICEF 2020), stating that the organizational staff includes an adequate number of persons with disabilities, but also undertakes efforts to raise awareness on disability issues. Second, it aims to "develop leadership on the rights of children with disabilities and build capacity among [its] staff and [its] partners" (UNICEF 2020). This means engaging in collaborative relationships with other UN stakeholders as well as actors from civil society, academia, or the private sector. The third goal is to "mainstream disability across all of our policies and programs, both in development and humanitarian action" (UNICEF 2020). UNICEF mostly implements programs in different countries, predominantly in the Global South, in order to support them in the implementation of the CRPD.

As one of the leading IOs in the global social policy field, the World Bank is also considering disability. Its goal is to "integrate disability into development through its analytical work, data and good-practice policies" and to include disability-related issues in its operations (World Bank 2020). Besides the World Report on Disability (WHO 2011) that has been published together with WHO to give a comprehensive image of the global status quo in disability policy, the World Bank has a focus on the inclusion of disability and disabled persons in its own work. As mentioned in its Disability Inclusion and Accountability Framework, the guiding principles in the World Bank's disability-inclusive work are based on the CRPD and encompass nondiscrimination and equality, accessibility, inclusion and participation, as well as partnership and collaboration (McClain-Nhlapo et al. 2018). This suggests a rights-based perspective of the organization that is in slight contrast to its previous collaboration on this issue with WHO. 


\section{The Economic Model}

A third dimension of disability policy that can be found in the literature has emerged in close relation to the shift from the medical to the social model and, therefore, has implications for the understanding and setup of the global disability policy field: an economic definition. From this perspective, disability is understood as a "health-related inability or a person's functional limitations on the amount or kind of work that disabled people can perform", with associated calls for policy solutions to remove these barriers (Jeon and Haider-Markel 2001, 216). Consequently, disability policymaking is supposed to aim at an inclusion of persons with disability into the labor market in order to have them contribute to the economic success of a country. Moving toward the establishment of such inclusive environments - even if most of them have not yet been implemented successfully-implies a shift from a welfare system for disabled people to a 'workfare' system (Peck 2001). The underlying assumption of this approach is that citizens who benefit from the welfare system need to contribute by participating in the labor market-a system of conditionality that is increasingly implemented by Western welfare states (Geiger 2017; Soldatic and Chapman 2010). The IO that exerts a particular influence on the development of such a model is the Organisation for Economic Co-operation and Development (OECD). In a collection of country reports from 2003, the OECD discusses opportunities to integrate disabled people into society in general as well as ways to secure their income by building inclusive structures in the labor market (OECD 2003). Another series of books published between 2007 and 2010 called Sickness, Disability and Work: Breaking the Barriers also examined different country case studies according to the inclusiveness of their employment structure for persons with disabilities (OECD 2010). A similar agenda is set by the ILO, which has continuously extended its instruments in regard to the rights of persons with disabilities. The ILO adopted a first recommendation concerning Vocational Rehabilitation of the Disabled (R099) in 1955 in order to "meet the employment needs of the individual disabled person and to use manpower resources to the best advantage" (ILO 1955). The recommendation was then renewed in 1983 (Rl68) and led to the technical Vocational Rehabilitation and Employment (Disabled Persons) Convention (C159), which entered into force in 1985. 


\section{Regional Organizations}

The global disability policy field not only consists of IOs but also of regional organizations. As the first-ever supranational organization to sign an international human rights treaty, namely the CRPD, the European Union (EU) has a disability strategy that addresses eight priority areas: accessibility, participation, equality, employment, education and training, social protection, health, and external action (European Commission 2010). One main objective of the EU is the collection of comprehensive information and data on the implementation status of the CRPD in its member states. For instance, it has launched the European Agency for Special Needs and Inclusive Education, an independent organization that provides information about the schooling of persons with special needs in the member states. Even broader thematically is the Academic Network of European Disability Experts, which offers a database summarizing the implementation status of the Convention in regard to the most important topics, such as accessibility, education, or employment.

There is significant variation in the ways in which other regional IOs address disability rights. Two examples stand out because of their explicit strategies and policies. The African Union introduced two African Decades of Disabled Persons (2000-2009 and 2010-2019), which led to the recent adoption in January 2018 of an additional Protocol to the African Charter on Human and People's Rights on the Rights of Persons with Disabilities. The main purpose of the Protocol is "to promote, protect and ensure the full and equal enjoyment of all human and people's rights by all persons with disabilities, and to ensure respect for their inherent dignity" (African Union 2018, 5). Similarly, the Association of Southeast Asian Nations (ASEAN) adopted the Enabling Masterplan 2025 in November 2018 to mainstream the rights of persons with disabilities. This is conceived as an additional framework in support of the implementation of the CRPD in ASEAN member states (ASEAN 2018).

\section{Mapping the Global Disability Policy Field Based ON Twitter Data}

As we have already shown in this chapter, the population of IOs in the field of disability policy is diverse and contains many different organizations. Besides these international and supranational actors, the global disability policy sphere also comprises a variety of NGOs, mostly DPOs, that 
are engaged in the advocacy of disability rights. During the disability rights movements in the late twentieth century, these organizations played a crucial role in achieving self-advocacy, using international advocacy networks to share ideas and information (Priestley 2007). Moreover, in the context of the CRPD, DPOs have had an influential role since the drafting process, with significant involvement in the meetings of the Ad Hoc Committee (Degener and Begg 2017; Stein and Lord 2009). The close interaction between the member states of the Convention with stakeholders from civil society is also explicitly mentioned in Article 32 (United Nations 2006) and is further considered in the monitoring process of the Committee. Moreover, despite the differences in disability concepts and policies, the UN endeavors to establish programs that combine forces for the promotion of disability rights outside and inside the organization. For instance, the Inter-Agency Support Group for the CRPD was established in 2006 in order to integrate disability into the UN system, and the UN Partnership on the Rights of Persons with Disabilities brings together different stakeholders-including the ILO, UNESCO, or WHO as well as civil society organizations, such as the International Disability Alliance or the IDDC-to advance disability rights on a global scale.

Consequently, it can be assumed that IOs and DPOs use means of soft governance-that is, institutional and discursive resources- to diffuse and implement the standards set in the CRPD (see Niemann et al. in this volume). We argue that in order to do so, they build networks to collectively shape discourses around disability rights. This makes an analysis of such networks a promising approach to better understand the global disability policy field. However, mapping global networks that comprise a diverse set of global actors is challenging (Dicken et al. 2001). In order to address this challenge and to acknowledge the increasing relevance of new ICTs for the exchange of information, we draw on Twitter data.

The social media platform Twitter is used for real-time information and discussion and has gained increasing importance in politics over recent years (Weller 2014). Different political actors contribute to the platform to promote their ideas, for mobilization or organization (Dubois and Gaffney 2014; Guo and Saxton 2014; Conover et al. 2012). Users can participate in issue-specific discussions by adding a so-called hashtag ('\#') to a word (e.g., \#crpd or \#disability). Moreover, users can interact with other users by mentioning them (i.e., placing the $@$-symbol in front of a username so that the user in question receives a notification), replying to them (a mention at the beginning of a tweet), or retweeting them 
(republishing another user's tweet). By collecting tweets on a specific topic and extracting the interactions made in these tweets, issue-specific Twitter networks can be mapped.

For the present analysis, we obtained Twitter data that were published during the COSPs to the CRPD in the years 2013 to 2017. To identify references to the CRPD and to disability policy, we filtered for specific hashtags such as \#crpd, \#cosp, or \#disability. In total, we identified 44,545 tweets, which led to an overall network consisting of 16,712 accounts (socalled nodes) and 38,737 interactions (edges). We used techniques of social network analysis (SNA) to map the network and the relations between the different actors and to identify central actors (Borgatti et al. 2013). SNA is particularly suited to exploring the 'hidden influence' that actors exert in a given organizational field because it shifts the unit of analysis from individual attributes of actors to their embeddedness in social relations (Jörgens et al. 2016; Kolleck et al. 2017).

In order to present an overall impression of the network, Fig. 9.1 shows the network with labels for the 20 most central actors according to eigenvector centrality. This measure represents the centrality of a node in relation to the centrality of the nodes it is directly connected to. It can therefore be seen as an indicator of an actor's popularity in a network (Borgatti et al. 2013). The size of the labels is proportional to the eigenvector centrality value. The figure indicates that the most central nodes belong to the UN, namely the official UN account, the UN entity for the empowerment of women, the account of the secretariat of the CRPD (UN Enable) and UNICEF. Other UN accounts that appear among the top 20 are directly linked to the division and department to which the CRPD is assigned (i.e., the Division for Social Policy and Development (DSPD $)^{4}$ in the UNDESA) or represent the official Special Rapporteur on the rights of persons with disabilities. In addition, the International Disability Alliance and the Ecuadorian president, Lenín Moreno, show high centrality values. Other central actors are mostly NGOs and DPOs or their representatives, such as the IDDC, Lumos, the European Disability Forum (EDF), or Catherine Naughton (EDF Director). The clustering of these nodes in the network suggests that they are closely interconnected. Aside from that, the lack of other IOs in this list is quite remarkable, even though for the most part they are not explicitly concerned with disability

${ }^{4}$ Today, the DSPD is part of the DISD. 


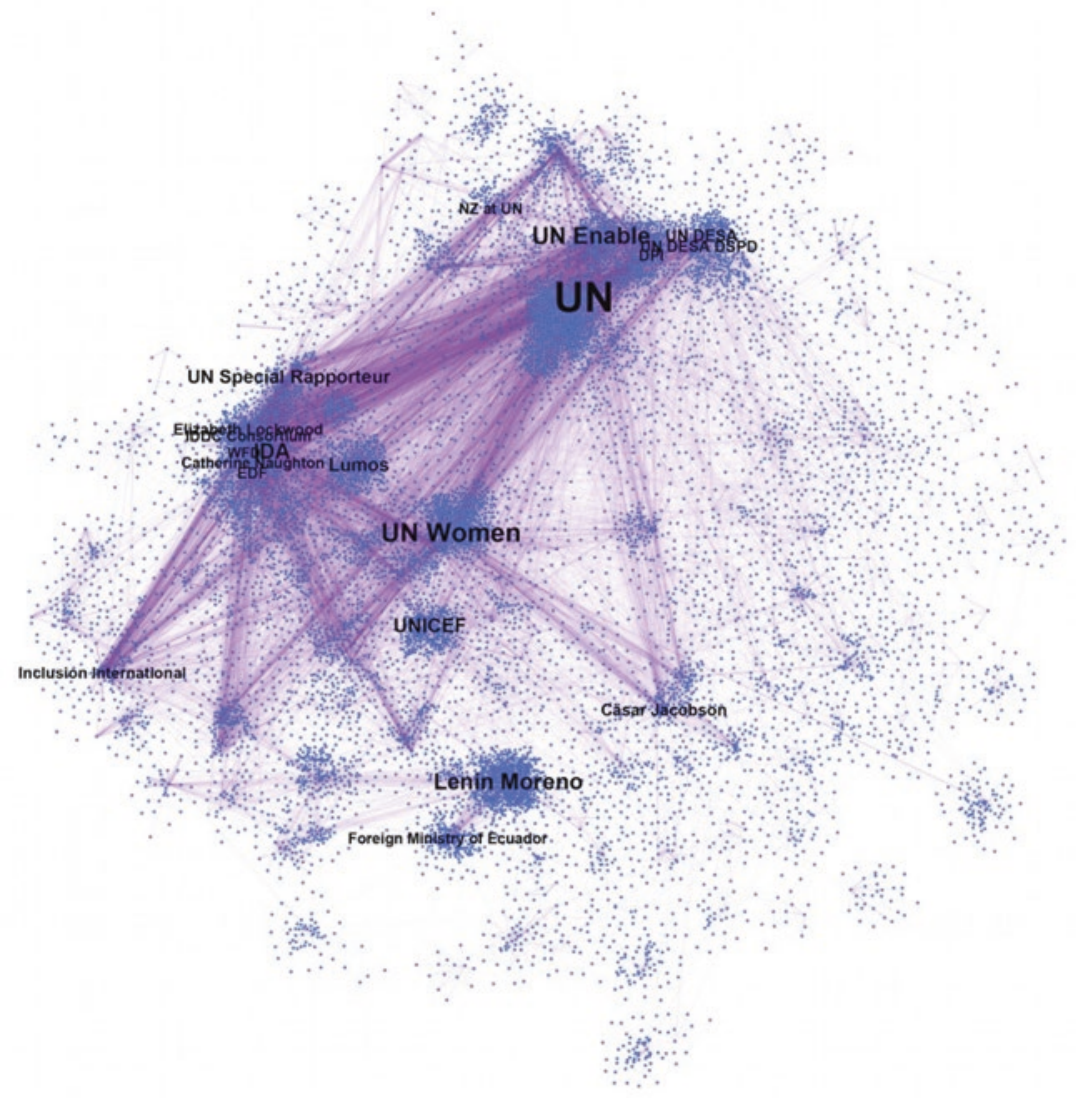

Fig. 9.1 The overall twitter network of the COSPs 2013-2017

rights (see Section "Background of (Global) Disability Policy Discourse and Involvement of IOs").

Figure 9.2 provides a reduced network containing only the interactions between IO-related accounts. In this network, the size of the nodes represents the eigenvector centrality. As could be observed in the overall network, the most central nodes in the IO-IO interaction network belong to the aforementioned UN agencies. According to the graph, one particularly prominent organization is the UN International Telecommunication Union (ITU), a specialized agency that is established to facilitate global 


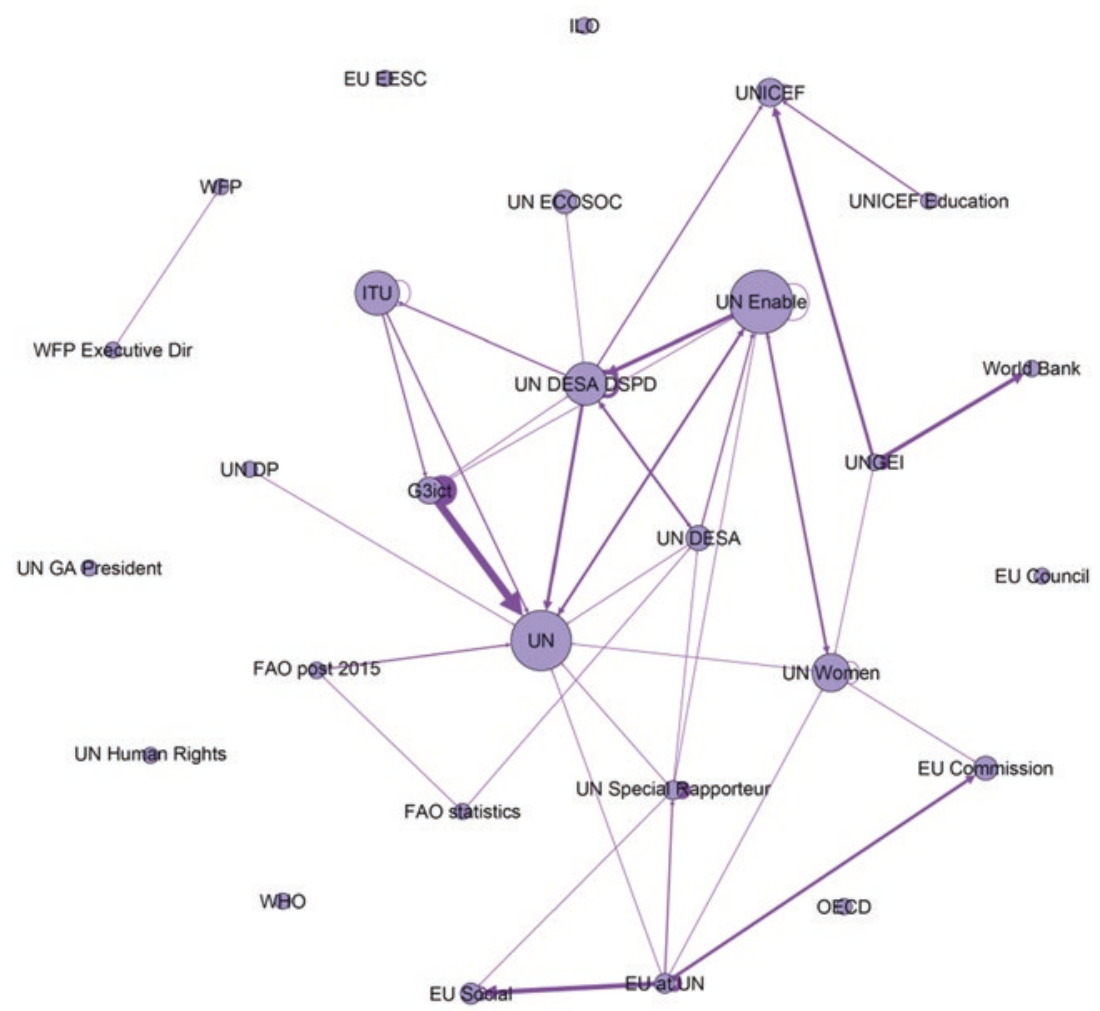

Fig. 9.2 Twitter network of the most central IOs during the COSPs 2013-2017

connectivity. This is not surprising given that the organization is concerned with ICTs and the analyzed data were created using ICTs. Hence, it can be assumed that the ITU has a particular interest in appearing prominently in online social media. Rather remarkable is the position of WHO and the OECD. Though among the most influential actors in global disability policy, they seem to be excluded from the Twitter network. However, the extent to which this is due to an actual lack of interaction with other relevant actors or rather a general reluctance to engage in social media activity cannot be ascertained from this data.

When looking at the IO-NGO interactions (see Fig. 9.3), we find similar results to the overall network. Aside from UN accounts directly related 
to disability rights, the DPOs hold the most central positions in the network (in regard to both the centrality value and the actual position). Overall, it can be observed from this analysis of Twitter data that both IOs and NGOs use Twitter to exchange information. The most central actors in the network are UN agencies directly related to disability policy as well as DPOs. This suggests that those actors with an explicit agenda for disability policy use the available channels - including online platforms- to promote disability rights, whereas the topic is less important to others. However, it must first be noted that the data was collected in the context of a UN event, making it more likely for UN actors to participate, and second, that social media platforms are still used to different extents by official political actors. For this reason, inferences from these results must be made with caution.

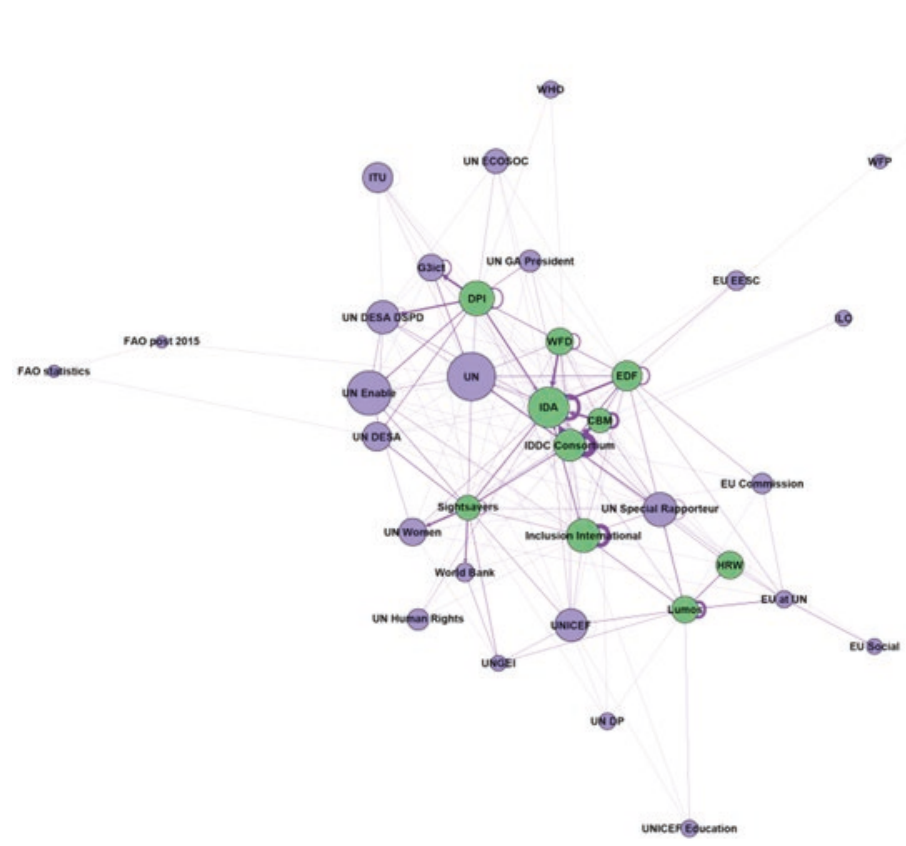

Fig. 9.3 Twitter network of central IOs and NGOs 


\section{Main Topics in Global Disability Policy}

The presentation of IOs in the field has already shown that disability is often discussed in conjunction with other forms of discrimination and can hardly be discussed separately from other social and development policy issues. Hence, in the context of disability rights, a specific focus is placed on other marginalized groups who need more immediate consideration when they also have a form of disability. Most commonly, children (or youth) and women (and girls) with disabilities are discussed-often in combination-in the global disability discourse as groups prone to multiple marginalization. First of all, women with disabilities (Article 6) and children with disabilities (Article 7) are addressed with specific articles in the Convention. Moreover, a closer look at the thematic setup of the COSPs to the CRPD shows that the specific consideration of children and youth (main theme 2012, sub-themes 2014 and 2015) as well as women and girls (main theme 2012, sub-themes 2015 and 2018) is important in discussions about the implementation of the Convention. Also, the General Comment No. 3 by the CPRD Committee pays particular attention to women and children, stating that they "face barriers in most areas of life" (United Nations 2016a, 1). According to the UN, the main dangers for women and children with disabilities are poverty, lack of health care, the general degree of social inclusion and participation, and lack of employment and equal education (United Nations 2014; United Nations 2016a). However, it must also be noted that children and women with disabilities in the Global North face different challenges to those in the Global South and that the focus of politicians and advocates can differ in light of this. Being at the intersection of several forms of marginalization and discrimination, the topic of children and women with disabilities is dealt with in close cooperation between the respective units of the CRPD, the CRC and the Convention on the Elimination of All Forms of Discrimination Against Women (Watson 2012; Kayess et al. 2014; see also Holzscheiter in this volume).

One of the most controversially discussed topics during the meetings of the Ad Hoc Committee to the CRPD was that of education (Biermann and Powell 2014; de Beco 2018). The main argument involved the position on whether the Convention text should exclusively demand inclusive education or whether schooling in separated special schools or classes should still be maintained as an option. Although member states are asked in the final version in Article 24 to "ensure an inclusive education system 
at all levels" (United Nations 2006, 16), the schooling of persons with disabilities still differs widely across the world. The CRPD Committee has emphasized the importance of education as a disability rights issue by publishing the General Comment No. 4 on inclusive education (United Nations 2016b). At the same time, WHO's ICF is still used to justify special education systems. From a medicalized perspective, the classification can be useful for the allocation of resources (Schiemer 2017). As is the case for children and women with disabilities, education for persons with disabilities on a broader, more global level also needs to address different issues depending on the region. In countries of the Global North such as Germany, the main argument is between supporters of a traditional segregation system with special schools and proponents of a comprehensive, inclusive system. In contrast, countries in the Global South (e.g., Nigeria) are still struggling to provide any sort of education for disabled children (Biermann 2016). Hence, DPOs emphasize the importance of assuring general access of persons with disabilities to the education system, first and foremost, though they also support the inclusive approach.

In an increasingly digitalized world, another crucial topic for disability policy is technology. As different scholars point out, the provision of assistive and accessible technology is mandatory for the inclusion of people with disabilities in policymaking processes. For instance, Trevisan and Cogburn (2019) emphasize that official UN conferences lack accessibility and thereby exclude disability rights advocates from participation. Only the COSPs to the CRPD meet the needs of disabled persons, making it difficult to represent persons with disabilities in events that do not explicitly address disability policy. Moreover, Alper and Raharinirina (2006) have shown through their systematic review that assistive technologies for individuals are also still rare. This topic is also taken into account by different IOs in the context of disability policy. Just recently, "technology, digitalization and ICTs for the empowerment and inclusion of persons with disabilities" was announced as a sub-theme for the CRPD COSP 2019, making technology a sub-theme at the conference for the third time (after 2012 and 2016). A UN specialized agency that directly addresses the intersection of ICTs and disability - and that appeared prominently in the CRPD Twitter network-is the ITU. In order to meet the needs of persons with disabilities in using ICTs, as is required by Article 9 of the CRPD, the ITU provides policymakers with reports and guidelines as well as trainings and capacity-building programs. This material is published to enable member states of the ITU to make their ICTs accessible. Discussing 
accessible and assistive technology in the context of global disability policy is particularly interesting as it represents the part of the field that is most profitable for private business actors. Hence, new partnerships between public (inter-)governmental actors, civil society and businesses are already forming at the global level and can influence future disability policymaking (Goggin and Newell 2007; Stienstra et al. 2007).

\section{Conclusion}

The main objective of this chapter was to examine disability as a 'new' global social policy theme. Both the development of global disability policy and the involvement of different IOs in that organizational field were examined. In order to approach a mapping of the global disability policy network and to identify particularly central actors as well as their interactions, social network analysis was used to map the Twitter network surrounding the UN CRPD. Finally, the main discourses of the field were identified.

The development of disability policy, both at national and global levels, was mainly influenced by a shift from the general conceptualization of disability as a negative condition of individuals that needed to be reacted to with care and welfare in order to assimilate them to the social norm (the medical model), toward a perception of disability as barriers and limitations imposed by society that disabled persons have to face (the social model). The two main IOs in the field-the UN agencies assigned to the CRPD on the one hand and WHO on the other-stand divided by this discourse. While the UN tends to promote the right of persons with disabilities to a society and environment without barriers, WHO tends to maintain the medicalization of disability. However, since the adoption of the CRPD, the UN has undoubtedly been the dominant actor, driven by its monitoring system that obliges its member states to regularly disclose their disability policy. As Búrca, Keohane, and Sabel (2013) note, this rather new mode of governance can best be described as 'experimentalist governance' (see also Sabel and Zeitlin 2010). Experimentalist governance is characterized by "a set of practices involving open participation by a variety of entities (public or private), lack of formal hierarchy within governance arrangements, and extensive deliberation throughout the process of decision making and implementation" (de Búrca et al. 2013, 16). In an iterative process, it is left to the member states of an international treaty to establish ways of incorporating the goals of the treaty into their 
domestic policy framework and, in return, their performance is regularly assessed by IO bodies. This iterative process can create a dynamic of peer pressure that often leads to a continuous strengthening of policy targets accompanied by a gradually evolving institutionalization and formalization of the procedural rules.

This structure offers diverse opportunities for IOs to engage in global disability policy. However, as the Convention is still rather new, there is currently not much research on the involvement and especially the interplay of different actors, such as the UN and WHO. To date, only the important role played by civil society organizations and their robust relationship with the UN bodies have been emphasized by different authors (Lord and Stein 2008; Degener and Begg 2017; de Búrca et al. 2013). Our empirical mapping of the CRPD Twitter network also suggests that the CRPD-related accounts are well connected to other UN agencies and to crucial civil society actors, while WHO is rather excluded from these discursive networking activities (see also Schuster et al. 2019). It will be interesting to see how the organizational field around global disability policy will develop in the future and what role WHO will play. Moreover, the increasing focus on persons with disabilities as 'human capital' - with the OECD as a driving force behind an economic model- has the potential to steer global disability policies toward the creation of workfare states. In theory, this is in line with the social model and the focus on the right to inclusion. Consequently, critics of the social model state that a mere focus on the social barriers neglects the bodily impairments, and that this in turn can deny the necessity of medicalization (Thomas 2004). Hence, scholars have recently made attempts to synthesize the medical and the social model in order to take into account "the complete background of an individual's life and living", including environmental and personal factors (Barnes 2011, 66). Adding the economic model, future disability policyboth at global and national levels - will have to be made within this area of tension between the different conceptualizations, thereby leaving space for IOs to exert their influence.

\section{REFERENCES}

Abbott, Kenneth W., Jessica F. Green, and Robert O. Keohane. 2016. "Organizational Ecology and Institutional Change in Global Governance." International Organization 70 (2): 247-277. doi:https://doi.org/10.1017/ S0020818315000338. 
Adam, Silke, and Hanspeter Kriesi. 2007. "The Network Approach." In Theories of the Policy Process, edited by Paul A. Sabatier. 2nd ed., 189-220. Boulder, CO: Westview Press.

African Union. 2018. Protocol to the African Charter on Human Peoples' Rights on the Rights of Persons with Disabilities in Africa. https://au.int/sites/ default/files/treaties/36440-treaty-protocol_to_the_achpr_on_the_rights_ of_persons_with_disabilities_in_africa_e.pdf. Accessed January 29, 2020.

Alper, Sandra, and Sahoby Raharinirina. 2006. "Assistive Technology for Individuals with Disabilities: A Review and Synthesis of the Literature." Journal of Special Education Technology 21 (2): 47-64. doi:https://doi. org/10.1177/016264340602100204.

Arnardóttir, Oddný M., and Gerard Quinn, eds. 2009. The UN Convention on the Rights of Persons with Disabilities: European and Scandinavian Perspectives. International studies in human rights v. 100. Leiden, Boston: Martinus Nijhoff Publishers.

ASEAN. 2018. ASEAN Enabling Masterplan 2025: Mainstreaming the Rights of Persons with Disabilities. https://asean.org/storage/2018/11/ASEANEnabling-Masterplan-2025-Mainstreaming-the-Rights-of-Persons-withDisabilities.pdf. Accessed January 29, 2020.

Barnes, Colin. 2011. "Understanding Disability and the Importance of Design for All." Journal of Accessibility and Design for All 1 (1): 55-80.

Barnes, Colin, and Geof Mercer, eds. 2004. Implementing the Social Model of Disability: Theory and Research. Leeds: Disability Press.

Barnett, Michael N., and Martha Finnemore. 1999. "The Politics, Power, and Pathologies of International Organizations." International Organization 53 (4): 699-732. doi:https://doi.org/10.1162/002081899551048.

Bauer, Michael W., Christoph Knill, and Steffen Eckhard. 2017. International Bureaucracy. London: Palgrave Macmillan.

Beco, Gauthier de. 2018. "The Right to Inclusive Education: Why Is There so Much Opposition to Its Implementation?" International Journal of Law in Context 14 (3): 396-415. doi:https://doi.org/10.1017/S174455231 7000532 .

Biermann, Julia. 2016. "Different Meanings? The Translation of Inclusive Education in Nigeria." Journal of Inclusive Education Research and Development Education 39 (3): 10-15.

Biermann, Julia, and Justin J.W. Powell. 2014. "Institutionelle Dimensionen inklusiver Schulbildung - Herausforderungen der UN-Behindertenrechts konvention für Deutschland, Island und Schweden im Vergleich [Institutional Dimensions of Inclusive Education - a Comparison of the Challenges of the UN Convention on the Rights of Persons with Disabilities for Germany, Iceland and Sweden]." Zeitschrift für Erziehungswissenschaft 17 (4): 679-700. doi:https://doi.org/10.1007/s11618-014-0588-0. 
Borgatti, Stephen P., Martin G. Everett, and Jeffrey C. Johnson. 2013. Analyzing Social Networks. Los Angeles: Sage.

Búrca, Gráinne de, Robert O. Keohane, and Charles F. Sabel. 2013. New Modes of Pluralist Global Governance. New York: New York University Public Law and Legal Theory Working Papers. Paper 386.

Conover, Michael D., Bruno Goncalves, Alessandro Flammini, and Filippo Menczer. 2012. "Partisan Asymmetries in Online Political Activity." EPJ Data Science 1 (6): 1-19.

Degener, Theresia, and Andrew Begg. 2017. "From Invisible Citizens to Agents of Change: A Short History of the Struggle for the Recognition of the Rights of Persons with Disabilities at the United Nations." In the United Nations Convention on the Rights of Persons with Disabilities. Vol. 18, edited by Valentina Della Fina, Rachele Cera, and Giuseppe Palmisano, 1-39. Cham: Springer International Publishing.

Della Fina, Valentina, Rachele Cera, and Giuseppe Palmisano, eds. 2017. The United Nations Convention on the Rights of Persons with Disabilities. Cham: Springer International Publishing.

Dicken, Peter, Philip F. Kelly, Kris Olds, and Henry Wai-Chung Yeung. 2001. "Chains and Networks, Territories and Scales: Towards a Relational Framework for Analysing the Global Economy." Global Networks 1 (2): 89-112. doi:https://doi.org/10.1111/1471-0374.00007.

Drake, Robert F. 1999. Understanding Disability Policies. Basingstoke: Macmillan. Dubois, Elizabeth, and Devin Gaffney. 2014. "The Multiple Facets of Influence." American Behavioral Scientist 58 (10): 1260-1277. doi:https://doi. org/10.1177/0002764214527088.

European Commission. 2010. European Disability Strategy 2010-2020: A Renewed Commitment to a Barrier-Free Europe. https://www.cedefop. europa.eu/en/news-and-press/news/european-disability-strategy-20102020-renewed-commitment-barrier-free-europe. Accessed January 29, 2020.

Geiger, Ben B. 2017. "Benefits Conditionality for Disabled People: Stylised Facts from a Review of International Evidence and Practice." Journal of Poverty and Social Justice 25 (2): 107-128. doi:https://doi.org/10.1332/17598271 7X14939739331010.

Goggin, Gerard, and Christopher Newell. 2007. "The Business of Digital Disability." The Information Society 23 (3): 159-168. doi:https://doi. org/10.1080/01972240701323572.

Guo, Chao, and Gregory D. Saxton. 2014. "Tweeting Social Change." Nonprofit and Voluntary Sector Quarterly 43 (1): 57-79. doi:https://doi. org/10.1177/0899764012471585.

Harpur, Paul. 2012. "Embracing the New Disability Rights Paradigm: The Importance of the Convention on the Rights of Persons with Disabilities." Disability \& Society 27 (1): 1-14. doi:https://doi.org/10.1080/0968759 9.2012.631794. 
ILO. 1955. Vocational Rehabilitation (Disabled) Recommendation. R099. https://www.ilo.org/dyn/normlex/en/f? p=NORMLEXPUB: 12100:0::NO::P12100_ILO_CODE:R099. Accessed January 29, 2020.

Jakobi, Anja P. 2009. "Global Education Policy in the Making: International Organisations and Lifelong Learning." Globalisation, Societies and Education 7 (4): 473-487. doi:https://doi.org/10.1080/14767720903412275.

Jeon, Yongjoo, and Donald P. Haider-Markel. 2001. "Tracing Issue Definition and Policy Change: An Analysis of Disability Issue Images and Policy Response." Policy Studies Journal 29 (2): 215-231. doi:https://doi. org/10.1111/j.1541-0072.2001.tb02087.x.

Jörgens, Helge, Nina Kolleck, and Barbara Saerbeck. 2016. "Exploring the Hidden Influence of International Treaty Secretariats: Using Social Network Analysis to Analyse the Twitter Debate on the "Lima Work Programme on Gender." Journal of European Public Policy 23 (7): 979-998. doi:https://doi. org/10.1080/13501763.2016.1162836.

Kayess, Rosemary, and Phillip French. 2008. "Out of Darkness into Light? Introducing the Convention on the Rights of Persons with Disabilities." Human Rights Law Review 8 (1): 1-34. doi:https://doi.org/10.1093/ hrlr/ngm044.

Kayess, Rosemary, Therese Sands, and Karen R. Fisher. 2014. "International Power and Local Action - Implications for the Intersectionality of the Rights of Women with Disability." Australian Journal of Public Administration 73 (3): 383-396. doi:https://doi.org/10.1111/1467-8500.12092.

Kolleck, Nina, Mareike Well, Severin Sperzel, and Helge Jörgens. 2017. "The Power of Social Networks: How the UNFCCC Secretariat Creates Momentum for Climate Education." Global Environmental Politics 17 (4): 106-126. https://doi.org/10.1162/GLEP_a_00428.

Lang, Raymond, Maria Kett, Nora Groce, and Jean-Francois Trani. 2011. "Implementing the United Nations Convention on the Rights of Persons with Disabilities: Principles, Implications, Practice and Limitations." ALTER European Journal of Disability Research 5 (3): 206-220.

Lord, Janet E., and Michael A. Stein. 2008. "The Domestic Incorporation of Human Rights Law and the United Nations Convention on the Rights of Persons with Disabilities." Washington Law Review 83 (4): 449-479.

McClain-Nhlapo, Charlotte Vuyiswa, Lauri Heikki Antero Sivonen, Deepti Samant Raja, Simona Palummo, and Elizabeth Acul. 2018. Disability Inclusion and Accountability Framework (English). Washington, DC: World Bank Group. http://documents.worldbank.org/curated/en/437451528442789278/ Disability-inclusion-and-accountability-framework. Accessed February 4, 2020. OECD. 2003. Transforming Disability into Ability: OECD.

OECD. 2010. Sickness, Disability and Work: Breaking the Barriers: OECD. 
Oliver, Michael. 1996. Understanding Disability: From Theory to Practice. New York: St. Martin's Press.

Peck, Jamie. 2001. Workfare States. New York, NY: Guilford Press.

Priestley, Mark. 1998. "Constructions and Creations: Idealism, Materialism and Disability Theory.” Disability \& Society 13 (1): 75-94. doi:https://doi. org/10.1080/09687599826920.

Priestley, Mark. 2000. "Adults Only: Disability, Social Policy and the Life Course." Journal of Social Policy 29 (3): 421-439. doi:https://doi.org/10.1017/ S0047279400005985.

Priestley, Mark. 2007. "In Search of European Disability Policy: Between National and Global." ALTER - European Journal of Disability Research 1 (1): 61-74. doi:https://doi.org/10.1016/j.alter.2007.08.006.

Rosenau, James N. 1995. "Governance in the Twenty-First Century." Global Governance 1 (1):13-43.

Sabel, Charles F., and Jonathan Zeitlin. 2010. Experimentalist Governance in the European Union: Towards a New Architecture. Oxford: Oxford University Press.

Schiemer, Margarita. 2017. Education for Children with Disabilities in Addis Ababa, Ethiopia: Developing a Sense of Belonging. Cham: Springer.

Schuster, Johannes, Helge Jörgens, and Nina Kolleck. 2019. "The Rise of Global Policy Networks in Education: Analyzing Twitter Debates on Inclusive Education Using Social Network Analysis." Journal of Education Policy 39 (3): 1-21. doi:https://doi.org/10.1080/02680939.2019.1664768.

Shakespeare, Tom. 2010. "The Social Model of Disability." In the Disability Studies Reader, edited by Lennard J. Davis, 266-273. New York: Routledge.

Soldatic, Karen, and Anne Chapman. 2010. "Surviving the Assault? The Australian Disability Movement and the Neoliberal Workfare State." Social Movement Studies 9 (2): 139-154. doi:https://doi.org/10.1080/14742831003603299.

Stein, Michael A. 2007. "Disability Human Rights." California Law Review 95 (1): 75-121.

Stein, Michael A., and Janet E. Lord. 2009. "Future Prospects for the United Nations Convention on the Rights of Persons with Disabilities." In the UN Convention on the Rights of Persons with Disabilities: European and Scandinavian Perspectives, edited by Oddný M. Arnardóttir and Gerard Quinn, 17-40. International studies in human rights (Volume 100). Leiden, Boston: Martinus Nijhoff Publishers.

Stienstra, Deborah, James Watzke, and Gary E. Birch. 2007. "A Three-Way Dance: The Global Public Good and Accessibility in Information Technologies.” The Information Society 23 (3): 149-158. doi:https://doi. org/10.1080/01972240701323564. 
Thomas, Carol. 2004. "Developing the Social Relational in the Social Model of Disability." In Implementing the Social Model of Disability: Theory and Research, edited by Colin Barnes and Geof Mercer, 32-47. Leeds: Disability Press.

Trevisan, Filippo, and Derrick L. Cogburn. 2019. "Technology and Grassroots Inclusion in Global Governance: A Survey Study of Disability Rights Advocates and Effective Participation." In Proceedings of the 52nd Hawaii International Conference on System Science, edited by Hawaii International Conference on System Sciences, 2205-2214. Honolulu, HI.

Uerpmann-Wittzack, Robert. 2018. "The Law-Making Function of the UN Committee on the Rights of Persons with Disabilities." Wroclaw Review of Law, Administration \& Economics 8 (2): 36-46. doi:https://doi.org/10.1515/ wrlae-2018-0032.

UN Enable. 2020. United Nations - Disability. https://www.un.org/development/desa/disabilities/. Accessed January 29, 2020.

UNESCO. 2020. Access for People with Disabilities. https://en.unesco.org/ themes/access-people-disabilities. Accessed January 29, 2020.

UNICEF. 2020. Disabilities. https://www.unicef.org/disabilities/. Accessed January 29, 2020.

United Nations. 2006. Convention on the Rights of Persons with Disabilities. https://www.un.org/development/desa/disabilities/convention-on-therights-of-persons-with-disabilities.html. Accessed January 29, 2020.

United Nations. 2014. "Youth with Disabilities: Note by the Secretariat." Unpublished manuscript, last modified October 10, 2019. https://www.un. org/development/desa/disabilities/conference-of-states-parties-to-theconvention-on-the-rights-of-persons-with-disabilities-2/seventh-session-ofthe-conference-of-states-parties-to-the-convention-on-the-rights-of-personswith-disabilities-10-12-june-2014.html.

United Nations. 2016a. "General Comment No. 3 (2016) on Women and Girls with Disabilities." Unpublished manuscript, last modified May 8, 2019. https://www.ohchr.org/EN/HRBodies/CRPD/Pages/GC.aspx.

United Nations. 2016b. "General Comment No. 4 (2016) on the Right to Inclusive Education." Unpublished manuscript, last modified October 17, 2018. https://www.ohchr.org/en/hrbodies/crpd/pages/gc.aspx.

Watkins, Amanda. 2014. Model Policy for Inclusive ICTs in Education for Persons with Disabilities. Paris: UNESCO.

Watson, Nick. 2012. "Theorising the Lives of Disabled Children: How Can Disability Theory Help?" Children \& Society 26 (3): 192-202. doi:https:// doi.org/10.1111/j.1099-0860.2012.00432.x.

Weller, Katrin, ed. 2014. Twitter and Society. Digital formations 89. New York, NY: Lang. 
WHO. 1980. "International Classification of Impairments, Disabilities, and Handicaps." https://apps.who.int/iris/handle/10665/41003. Accessed January 29, 2020.

WHO. 2011. World Report on Disability. Geneva: WHO. http://whqlibdoc.who. int/publications/2011/9789240685215_eng.pdf. Accessed March 2020.

World Bank. 2020. Disability Inclusion. https://www.worldbank.org/en/topic/ disability\#2. Accessed February 4, 2020.

Zürn, Michael. 2018. A Theory of Global Governance: Authority, Legitimacy, and Contestation. Oxford, United Kingdom: Oxford University Press.

Open Access This chapter is licensed under the terms of the Creative Commons Attribution 4.0 International License (http://creativecommons.org/licenses/ by $/ 4.0 /$ ), which permits use, sharing, adaptation, distribution and reproduction in any medium or format, as long as you give appropriate credit to the original author(s) and the source, provide a link to the Creative Commons licence and indicate if changes were made.

The images or other third party material in this chapter are included in the chapter's Creative Commons licence, unless indicated otherwise in a credit line to the material. If material is not included in the chapter's Creative Commons licence and your intended use is not permitted by statutory regulation or exceeds the permitted use, you will need to obtain permission directly from the copyright holder.

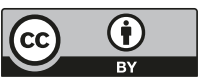

